Kunuz: Journal of Islamic Banking and Finance Vol. 1, No.2 (2021):95-106

Website: http://ejournal.iain-manado.ac.id/index.php/kunuz ISSN 2807-615X (online) ISSN 2807-680X (print)

\title{
PENGARUH PERUBAHAN ORGANISASI, STRESS KERJA \\ DAN INOVASI PRODUK TERHADAP KINERJA SUMBER DAYA INSANI PT. BANK BNI SYARIAH CABANG MAKASSAR
}

\author{
Nur Ifna \\ Fakultas Ekonomi dan Bisnis Islam Universitas Islam Negeri Alauddin Makassar \\ (UIN), Jl. M. Yasin Limpo, Kec. Somba Opu, Kab. Gowa, Sulawesi Selatan, \\ Indonesia, 92113 \\ E-mail: ifnanur19@gmail.com
}

\begin{abstract}
Tujuan penelitian ini adalah untuk mengetahui pengaruh perubahan organisasi, stres kerja, dan inovasi produk terhadap kinerja SDM perbankan syariah. Penelitian ini merupakan penelitian kuantitatif, dimana data yang digunakan adalah data primer yaitu data yang diperoleh langsung dari responden penelitian dengan menggunakan penyebaran kuesioner sebanyak 118 responden. Data tersebut kemudian dihitung menggunakan regresi linier berganda dan menggunakan alat bantu program SPSS Versi 21 dan diperoleh hasil untuk melihat uji hipotesis, baik uji F maupun uji $\mathrm{T}$. Hasil penelitian ini menunjukkan bahwa variabel perubahan organisasi, stres kerja dan inovasi produk saling berhubungan. Sedangkan R Square sebesar 0,121 dimana 12,1\% kinerja SDM dapat dijelaskan oleh perubahan organisasi, stres kerja dan inovasi produk. Sedangkan sisanya dapat dijelaskan oleh faktor lain di luar penelitian. Kemudian hasil hipotesis $\mathrm{F}$ menunjukkan bahwa perubahan organisasi (X1), stres kerja (X2) dan inovasi produk (X3) berpengaruh positif dan signifikan terhadap kinerja sumber daya manusia pada PT Bank BNI Syari'ah Cabang Makassar dengan nilai 0,002<0,05.
\end{abstract}

Keywords: Inovasi Produk; Kinerja Sumber Daya Manusia; Perubahan Organisasi; Stres Kerja 


\section{PENDAHULUAN}

Sumber daya manusia di Indonesia menjadi faktor utama dalam melaksanakan pembangunan di Indonesia. Terjadinya perubahan yang begitu cepat di semua aspek kehidupan sehingga berakibat adanya dorongan globalisasi yang tidak dapat dihindari begitu saja khususnya bagi sumber daya manusia. Perkembangan inilah yang membuat dunia bisnis turut tertekan oleh dilema peningkatan produktivitas dan peningkatan kinerja untuk semua sumber daya manusia sehingga mampu mencapai sesuai target perusahaan.

Perubahan yang disebabkan oleh perkembangan dunia memunculkan banyak reaksi terutama terhadap reaksi karyawan. Salah satunya adalah reaksi positif dengan menunjukkan peningkatan kinerja kerja dan kepuasan kerja. Namun terdapat pula reaksi negatif yaitu resistensi terhadap perubahan yang menunjukkan dengan meningkatnya intensi karyawan untuk keluar dari sebuah organisasi atau perusahaan yang menunjukkan menurunnya kepuasan kerja, kepercayaan diri terhadap organisasi bahkan terjadinya konflik karyawan yang berujung pada depresi yang berlebihan (Barling et al., 2003).

Indonesia sebagai salah satu Negara dengan penduduk muslim terbanyak sehingga menyebabkan Indonesia dipandang mampu menjalankan keuangan syariah. Lirikan investor dunia selalu tertuju kepada Indonesia, bahkan Indonesia memiliki segalanya termasuk kekayaan alamnya (Awwalin, 2014). Peluang ini mencuat seiring dengan perkembangan dunia perbankan yang berbasis syariah dimana dalam waktu 5 tahun terakhir perkembangan yang dicapai dapat dikatakan sangat signifikan. Berikut merupakan tabel indeks urutan negara-negara yang men-jalankan keuangan berbasis syariah dunia.

Gambar 1. Perkembangan Indeks Keuangan Syariah Dunia

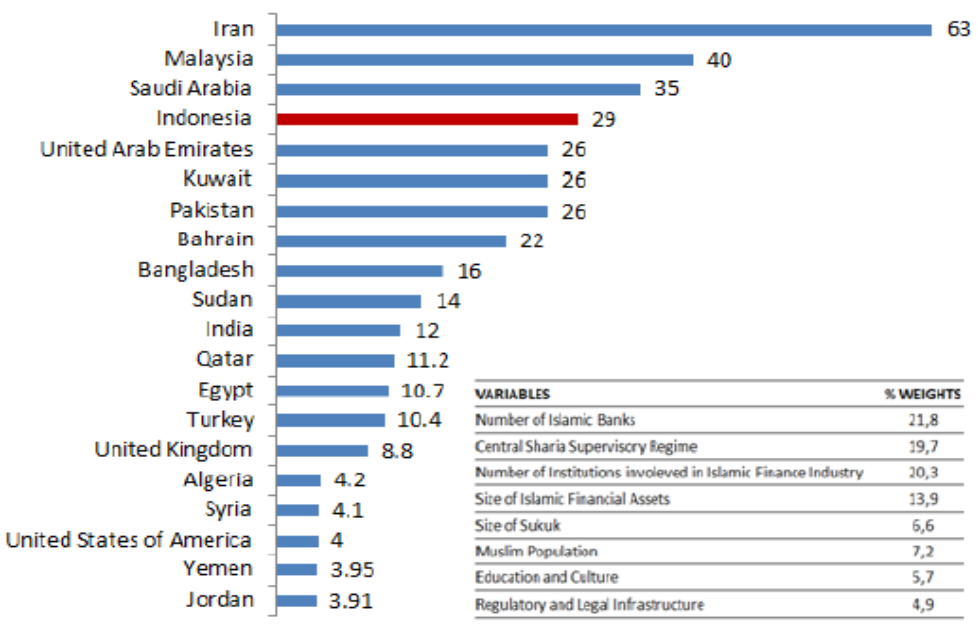

Sumber (Alamsyah, 2012)

Grafik tersebut menunjukan bahwa Indonesia masih berada pada urutan keempat teratas setelah Iran dengan nilai sebesar 63, kemudian disusul oleh Malaysia dengan skor 40, dan dilanjutkan oleh Saudi Arabia dengan total poin 35, 
barulah disusul oleh Indonesia dengan skor poin sebesar 29. Berdasarkan hal tersebut, dapat di katakan bahwa Indonesia akan mampu menempati urutan pertama sebagai negara yang mampu menjalankan keuangan Syariah beberapa tahun kedepan. Optimisme ini sejalan dengan laju ekspansi dan perkembangan bank dan non bank Syariah yang cukup tinggi apalagi volume penerbitan sukuk yang semakin meningkat (Gunawan dkk., 2017).

Semakin berkembang dunia dan perusahaan, persaingan dan tuntutan profesionalitas yang semakin tinggi tentunya memberikan efek yang lain bagi lingkungan kerja. Akibatnya akan timbul berbagai kecemasan dalam menghadapi masalah diri dan perkembangan dunia usaha. Walaupun kenyataan lain memperlihatkan tren yang positif bagi perusahaan. Bank Negara Indonesia (BNI) Syariah misalnya dengan pembenahan yang semakin maju mapu menarik pegawai untuk bekerjasama yang semakin lama semakin bertambah banyak sebagaimana berikut ini:

Tabel 1.

Jumlah Pekerja pada BNI Syariah

\begin{tabular}{ccc}
\hline Tahun & $\begin{array}{c}\text { Pekerja di Bank } \\
\text { Syariah }\end{array}$ & $\begin{array}{c}\text { Pekerja di BNI } \\
\text { Syar'iah }\end{array}$ \\
\hline 2012 & 15.224 orang & 70 orang \\
2013 & 24.111 orang & 89 orang \\
2014 & 26.717 orang & 95 orang \\
2015 & 28.560 orang & 93 orang \\
2016 & 29.065 orang & 97 orang \\
\hline
\end{tabular}

Sumber: Data BNI Syariah, 2016

Walaupun tren perkembangan karyawan di BNI Syariah semakin bertambah, namun pada faktanya terdapat berbagai masalah yang mampu memunculkan kecemasan bagi para pekerja. Salah satunya adalah stress kerja yang berlebihan. Dampak dari permasalahan tersebutpun dapat menyebabkan kerugian yaitu kecemasan yang berlebihan dan kadang membuat karyawan tidak sanggup untuk berbuat sesuai dengan tuntutan pekerjaan (Mas'ud, 2002). Selain itu, permasalahan yang dapat timbul adalah adanya perubahan status organisasi.

Terdapat tiga dimensi sikap terhadap perubahan yaitu: kecenderungan kognitif, efektif dan berperilaku. Setiap dimensi memiliki cara pandang berbeda dalam menghadapi suatu perubahan. Apakah diubah adalah sesuatu yang dianggap positif atau sesuatu negatif. Apabila perubahan dianggap positif, mudah untuk mencapai tujuan organisasi (Zulkarnain \& Hadiyani, 2014).

Adanya perubahan status sosial mampu menyebabkan terjadinya kinerja seorang karyawan mengalami penurunan ataupun sebaliknya. Daya saing organisasi mutlak diperlukan dengan tujuan untuk meningkatkan persaingan bisnis dalam sebuah perusahaan. Bukan hanya kedua faktor tersebut yang mampu mempengaruhi kinerja seorang pegawai mengalami peningkatan ataupun penurunan akan tetapi inovasi turut menentukan perkembangan sebuah perusahaan. Hal inilah yang kurang dimiliki oleh karyawan sehingga dalam melaksanakan pekerjaan selalu menemui kesulitan untuk berkembang sesuai tuntutan era modern (Rademakers, 2005). 
Keseimbangan pertumbuhan bank Syariah dan perkembangan konsumen bank Syariah membuat sebagian besar karyawan memaksakan diri untuk mampu bersaing dengan karyawan yang lain. Hal ini bertujuan untuk memberikan pelayan prima kepada konsumen dan mengikuti perkembangan perusahaan. Walau demikian, ada sejumlah permasalahan dalam sumber daya manusia di bank Syariah. Salah satu masalah terbesar sumber daya manusia Syariah adalah pihak perbankan kesulitan untuk mencari SDM perbankan Syariah yang kompeten dan mumpuni. Perbankan Syariah cenderung mengambil sumber daya manusia dari luar perguruan tinggi Syariah karena SDM di bank Syariah biasanya justru lebih mudah diberikan pengetahuan tentang perbankan Syariah.

\section{METODE PENELITIAN}

Jenis penelitian ini adalah penelitian deskriptif kuantitatif dengan objek penelitian yaitu karyawan PT Bank BNI Syariah Cabang Makassar. Populasi dalam penelitian ini merupakan seluruh karyawan dan pegawai pada PT Bank BNI Syariah Cabang Makassar. Sedangkan sampel yang digunakan dalam penelitian ini berjumlah 53 orang yang dipilih menggunakan teknik random sampling artinya semua populasi mempunyai kesempatan yang sama untuk dipilih menjadi sampel berdasarkan karakteristik yang dimaksud. Penelitian ini menggunakan data primer sebagai sumber data dimana data diperoleh secara langsung dari sumber asli (tidak melalui perantara) dalam bentuk kuisioner yang disebarkan pada PT Bank BNI Syariah Cabang Makassar. Teknik pengumpulan data yang digunakan dalam penelitian ini yaitu menggunakan observasi dan kuesioner. Data dianalisis menggunakan regresi linier berganda dan menggunakan alat bantu program SPSS Versi 21 dan diperoleh hasil untuk melihat uji hipotesis baik uji $\mathrm{F}$ maupun uji $\mathrm{T}$.

\section{HASIL DAN PEMBAHASAN}

\section{Kinerja Sumber Daya Insani}

Kinerja sumber daya insani berasal dari kata job performance atau actual performance (prestasi kerja atau prestasi sesungguhnya yang dicapai seseorang). Prestasi kerja merupakan hasil kerja secara kualitas dan kuantitas yang dicapai seorang karyawan dalam melaksanakan tugasnya sesuai dengan tanggung jawab yang diberikan kepadanya (Desky, 2014). Sumber Daya Insani adalah pegawai yang siap, mampu, dan siaga dalam mencapai tujuan-tujuan organisasi. Sebagaimana dikemukakan bahwa dimensi pokok sumber daya adalah kontribusinya terhadap organisasi, sedangkan dimensi pokok insani adalah perlakuan kontribusi terhadapnya yang akan menentukan kualitas dan kuantitas hidupnya.

Sumber Daya Insani juga menjadi kekuatan terbesar dalam Pengolahan semua sumber daya yang ada di bumi. Manusia diciptakan oleh Allah swt. sebagai khalifah di bumi untuk mengelola bumi dan sumber daya di dalamnya untuk kebahagiaan manusia itu sendiri, makhluk, dan seluruh alam semesta. Pada dasarnya, semua ciptaan Tuhan di bumi ini sengaja diciptakan oleh Allah untuk kemaslahatan umat manusia (Hardana, 2015). Manajemen sumber daya manusia dalam Islam yang didasari pasa suatu konsep bahwa setiap karyawan adalah 
manusia (bukan mesin) dan bukan semata menjadi sumber daya bisnis. Adapun manajemen Sumber Daya Berbasis Insani (SDI), menjadikan spiritualitas sebagai unsur vital dan tidak terpisahkan dari tempat kerja (Haryanto, 2017).

Bank Syariah dan lembaga keuangan perlu menyiapkan Sumber Daya Insani (SDI) yang berkualitas dan andal. Kualitas Sumber daya manusia sangat penting bagi perkembangan bank Syariah masa depan. Untuk dapat memajukan bisnis Islam menjadi sukses, maka membutuhkan orang-orang yang telah menguasai ilmu pengetahuan, Ilmu ekonomi dan syariah. Fakta yang terjadi saat ini, sebagian besar karyawan bank syariah dan lembaga keuangan yang bekerja lulusan universitas negeri diberi pelatihan singkat mengenai bank dan lembaga keuangan Islam. Berlatih seperti itu Tidak cukup untuk mengembangkan orangorang yang benar-benar kredibel dan berbakat di sektor perbankan dan institusional keuangan Islam (Ningsih, 2015).

Terkait lembaga keuangan, ada perbedaan Sumber Daya Insani (SDI) lembaga keuangan Islam dan konvensinal. Lembaga keuangan Islam, Sumber daya manusia yang tidak hanya mengontrol masalah operasional dan bisnis tapi mengenal dengan baik Hukum Ekonomi Islam atau Hukum Muamalah yang Ini berakar pada nilai-nilai Islam. Dari sudut pandang etika, itu harus menjadi esensi shiddiq dan kredibilitas. Apakah dasar dari semua karyawan untuk mencerminkan hal itu? Kejujuran para pemimpin Islam yang unggul. Karyawan lembaga keuangan Islam Harus profesional yang terampil, dapat menyelesaikan tugas dengan kerja tim di mana informasi didistribusikan secara merata di antara fitur bagan organisasi. Demikian pula tentang hadiah dan hukuman, itu sangat diperlukan sebagai implementasi yang tepat dari prinsip keadilan sesuai dengan Syariah (Al Hasan \& Maulana, 2016).

Pertumbuhan lembaga keuangan syariah khususnya perbankan Syariah di Indonesia yang terbilang cepat, seharusnya diseimbangi diseimbangi dengan sumber daya insani (SDI) yang professional dalam bidangnya baik dari aspek kualitas dan kauntitasnya. Sebab, Sumber Daya Insani (SDI) yang professional dalam bidangnya akan berpengaruh terhadap transaksi dan praktik dilapangan yang sering kali defleksi. Beberapa praktik nantinya akan menyimpang dan tidak sesuai syariah akibat ketidak tahuan Sumber Daya Insani (SDI) akan dasar ekonomi syariah (Sari Rezeki H: 2016).

\section{Uji Regresi Linier Berganda}

Analisis regresi linier berganda dilakukan untuk mengetahui besarnya variabel bebas yang mempengaruhi variabel terikat secara simultan atau parsial, dengan menguji hipotesis penelitian yang telah diidentifikasi sebelumnya. Hasil analisis regresi berganda adalah sebagai berikut:

Tabel 2.

Hasil Uji Linear Regresi Berganda

\begin{tabular}{lccr}
\hline Variabel & $\begin{array}{c}\text { Koefisien } \\
\text { Regresi(B) }\end{array}$ & T & Sig \\
\hline Perubahan Organisasi $\left(\mathrm{X}_{1}\right)$ & 0,130 & 1,368 & 0,174 \\
Stres Kerja $\left(\mathrm{X}_{2}\right)$ & $-0,140$ & $-3,385$ & 0,001 \\
Inovasi Produk $\left(\mathrm{X}_{3}\right)$ & 0,047 & 1,215 & 0,227 \\
\hline
\end{tabular}


Kunuz: Journal of Islamic Banking and Finance Vol. 1, No.2 (2021):95-106

Website: http://ejournal.iain-manado.ac.id/index.php/kunuz ISSN 2807-615X (online) ISSN 2807-680X (print)

\begin{tabular}{ll}
\hline Konstanta & $=4,090$ \\
$\mathrm{R}$ & $=0,348$ \\
R square & $=0,121$ \\
Adjusted R Square & $=0,098$ \\
F hitung & $=5,238$ \\
Signifikansi F & $=0,002$ \\
\hline
\end{tabular}

Sumber : Hasil Olahan SPSS 21

Berdasarkan hasil uji linear tersebut dihasilkan persamaan regresi sebagai berikut:

$$
Y=4,090+0,130 \times 1+-0,140 \times 2+0,047 \times 3
$$

a. Perubahan Organisasi

Analisis regresi menunjukkan koefesien regresi $(\beta 1)$ sebesar $0,130 \%$ terhadap kinerja sumber daya dengan signifikansi 0,174 ini berarti variabel perubahan organisasi(X1), tidak berpengaruh terhadap kinerja sumberdaya (y). Koefisien regresi $(\beta 1)$ sebesar 0,130 menyatakan bahwa setiap perubahan atau yang dilakukan oleh suatu organisasi (X1), maka akan membuat sebuah kinerja sumberdayanya menjadi lebih baik. Sebaliknya ketika terjadi penurunan bagi sebuah organisasi maka saat itupun kinerja sumberdaya menurun.

b. Stress Kerja

Analisis regresi menunjukkan koefesien regresi $(\beta 2)$ sebesar $0,140 \%$ terhadap kinerja sumberdaya dengan signifikansi 0,001 artinya variabel stres kerja (X2), berpengaruh secara signifikan terhadap kinerja sumberdaya. Ada-nya besaran koefisien regresi $(\beta 2)$ sebelumnya sehingga dapat dikatakan bahwa apabila stres kerja (X2) dalam sebuah organisasi menurun maka akan meningkatkan kinerja sumberdaya manusia dan sebaliknya ketika stres kerja meningkat maka akan menyebabkan kinerja sumberdaya dalam sebuah organisasi menurun sebesar $0,1 \%$.

c. Inovasi Produk

Analisis regresi menunjukkan koefesien regresi ( $\beta 1$ ) sebesar 0,047\% terhadap kinerja sumberdaya dengan signifikansi 0,227 berarti variabel inovasi produk (X3), tidak berpengaruh terhadap kinerja sumberdaya (y). Koefisien regresi $(\beta 1)$ sebesar 0,047 menyatakan bahwa setiap perubahan atau yang dilakukan oleh suatu organisasi dalam hal ini mampu berinovasi dengan baik (X3), maka akan membuat sebuah kinerja sumberdayanya menjadi lebih baik. Sebaliknya ketika sebuah organisasi tidak mampu berbuat atau me-munculkan ide yang lebih baik bagi sebuah organisasi maka saat itupun kinerja sumberdaya menurun.

\section{Hasil Uji Simultan}

Hasil uji simultan: variabel perubahan organisasi (X1), stres kerja (X2), dan inovasi produk (X3) terhadap kinerja sumberdaya (y) pada PT Bank BNI Syariah Cabang Makassar. secara simultan atau secara bersama-sama me-nunjukkan hasil nilai $\mathrm{F}$ hitung adalah sebesar 5,238 dengan signifikan $\mathrm{F}$ sebesar 0,002atau lebih kecil dari 0,05 (5\%), sehingga menolak H0 dan menerima Ha. Hasil ini menyatakan bahwa secara simultan semua variabel bebas yaitu variabel perubahan 
organisasi (X1), stres kerja (X2), dan inovasi produk (X3) terhadap kinerja sumberdaya (y) pada PT Bank BNI Syariah Cabang Makassar.

\section{Hasil Uji Parsial}

Tabel 3.

Penerimaan Hipotesis Uji Parsial

\begin{tabular}{cccc}
\hline Variabel & Nilai sig. & $\alpha(0.05)$ & Kesimpulan \\
\hline $\begin{array}{c}\text { Perubahan } \\
\text { organisasi }(\mathrm{X} 1)\end{array}$ & 0,174 & $0,174>0.05$ & $\begin{array}{c}\text { Ho diterima } \\
\text { Ha ditolak }\end{array}$ \\
$\begin{array}{c}\text { Stres kerja }\left(\mathrm{X}_{2}\right) \\
\begin{array}{c}\text { Inovasi produk } \\
\left(\mathrm{X}_{3}\right)\end{array}\end{array}$ & 0,001 & $0,001<0.05$ & $\begin{array}{c}\text { Ho diterima } \\
\text { Ha ditolak }\end{array}$ \\
\hline & Sumber : Hasil Olahan SPSS 21 & $0,227>0.05$ & $\begin{array}{c}\text { Ho diterima } \\
\text { Ha ditolak }\end{array}$ \\
\hline
\end{tabular}

a. Dampak perubahan organisasi pada kinerja sumber daya. Hasil penelitian menunjukkan nilai signifikansi sebesar 0,174 dibandingkan dengan tingkat signifikansi $(0,05)$, menunjukkan bahwa tingkat signifikansi lebih besar dari tingkat signifikansi $(0,174>0,05)$, sehingga Ho diterima Ha dan perubahan jaringan PT. Bank BNI Syariah Cabang Makassar tidak mempengaruhi kinerja.

b. Dampak stres kerja pada kinerja sumber daya. Hasil penelitian menunjukkan tingkat signifikansi 0,001 dibandingkan dengan tingkat signifikansi $(0,05)$. H0 ditolak dan Ha diterima karena menunjukkan tingkat signifikansi lebih besar dari tingkat signifikansi $(0,001<0,05)$. Oleh karena itu, stres kerja mempengaruhi kinerja. Departemen Sumber Daya Manusia PT Bank BNI Syariah Cabang Makassar

c. Dampak inovasi pada kinerja sumber daya. Hasil penelitian menunjukkan nilai signifikansi sebesar 0,227 dibandingkan dengan tingkat signifikansi $(0,05)$, menunjukkan bahwa tingkat signifikansi lebih besar dari tingkat signifikansi $(0,227>0,05)$, maka Ho ditolak Ha diterima Inovasi produk kinerja SDM divisi PT Bank BNI Syariah Cabang Makassar. Perubahan Organisasi terhadap Kinerja Sumberdaya Insani Perbankan Syariah di Kota Makassar

Sesuai dengan hasil analisis sebelumnya, di dapatkan hasil bahwa perubah-an organisasi tidak berpengaruh terhadap kinerja sumberdaya insani pada PT Bank BNI Syariah Cabang Makassar. Namun secara total semua variabel menunjukkan pengaruh yang signifikan dimana hasil ini mampu menjelaskan bahwa kinerja sumberdaya insani akan berjalan dengan baik apabila adanya perubahan, stres dalam bekerja an tentunya danya inovasi yang mampu mendukung proses per-kembangan perusahaan kepada pangsa yang lebih baik.

Kasus perubahan organisasi yang terjadi di Kota Makassar khususnya terhadap PT Bank BNI Syariah Cabang Makassar, sebagaimana seperti kejadian yang ditemukan di lapangan dapat dikatakan bahwa perubahan organisasi tidak 
terjadi dengan baik sehingga sebuah perusahaan tetap tertinggal dari perusahaan yang terlanjur lebih dulu berbenah. Sedangkan perubahan organisasi tidak menunjukkan pengaruh terhadap kinerja sumberdaya yang diakibatkan adanya faktor yang lain.

Bagi karyawan PT Bank BNI Syariah Cabang Makassar misalnya diantara 118 karyawan yang dimiliki banyak diantaranya tidak memiliki latar belakang yang sesuai dengan peruntuhan dunia kerja. Sehingga kalaupun perubahan organisasi dalam sebuah instansi atau perusahaan terjadi tapi tidak akan mempengaruhi kinerja sumberdaya ke arah yang lebih baik. Kinerja sumberdaya akan tetap berjalan seadanya saja tanpa adanya gebrakan yang lebih modern seperti perubahan yang terjadi pada instansi yang lain.

Hal ini sesuai dengan teori organisasi yang mencoba menjelaskan bahwa sebuah organisasi hanya dapat bertahan jika dapat melakukan perubahan dalam perjalanannya. Setiap perubahan lingkungan yang terjadi harus dicermati karena keefektifan suatu organisasi tergantung pada sejauh mana organisasi dapat menyesuaikan diri dengan perubahan tersebut. Menurut Robbins (2003) pada dasarnya semua perubahan yang dilakukan akan selalu mengarah pada peningkatan efektiftas organisasi dengan tujuan mengupayakan perbaikan kemampuan organisasi dalam menyesuaikan diri terhadap perubahan lingkungan serta perubahan perilaku anggota organisasi.

Selain dari faktor diatas, terdapat pula faktor yang lain yaitu tidak adanya aturan yang lebih ketat yang mengharuskan tiap-tiap karyawan mampu memberikan kinerja terhadap organisasinya melalui perubahan organisasi yang lebih baik. Sehingga ketika dunia kerja berjalan, para tenaga kerja dalam sebuah organisasi atau perusahan hanya berjalan dengan tuntutan kemauan sendiri. Walaupun kenyataannya ada aturan tersendiri yang mengatur tentang keberadaan tenaga kerja namun bukan berasal dari kantor cabang atau unit namun berasal dari kantor pusat perusahaan.

Penelitian ini sejalan dengan penelitian yang dilakukan oleh Jawas (2011) dimana sumber dari penolakan individual terhadap perubahan terdapat pada ciriciri atau karakteristik dasar manusia, misalnya persepsi, kepribadian, dan kebutuhan-kebutuhan. Menurut R. H Hall dalam Laihad dkk (2019) penolakan atau sikap menentang keorganisasian itu terjadi karena organisasi-organisasi yang bersifat konservatif, maka mereka secara aktif menentang perubahan. Sebagai contoh banyak pemerintah diberbagai negara dan badan-badan pemerintah ingin tetap melaksanakan apa yang sedang dilaksanakan selama bertahun-tahun, dan ini terlepas dari apakah kebutuhan akan jasa-jasa mereka berubah atau tetap sama saja.

Implikasi dari penelitian ini bahwa proses perubahan dalam sebuah organisasi merupakan langkah yang dapat diambil sebagai bahan pertimbangan tersendiri untuk perkembangan industri perbankan kedepannya. Sehingga pemilihan variabel dalam penelitian ini sudah tepat dan mampu di pertahankan sebaik mungkin. Adapun proses pembentukan kinerja akan muncul dari diri seseorang apabila proses yang di lalui sudah maksimal sehingga dapat memunculkan ke-inginan untuk membawa visi organisasi ke arah yang lebih modern. 


\section{Stress Kerja terhadap Kinerja Sumberdaya Insani Perbankan Syariah di Kota Makassar}

Berdasarkan hasil pengujian yang dilakukan di temukan bahwa stres kerja berpengaruh terhadap kinerja sumberdaya insani PT Bank BNI Syariah Cabang Makassar. Proses ini menjadi lebih jelas dimana stres kerja merupakan sebuah variabel yang mampu menjelaskan naik turunnya sebuah kinerja seseorang sehingga mampu memberikan sebuah perubahan pada perusahaan. Stres kerja akan terlihat ketika digunakan untuk mengukur tingkat kinerja sumberdaya seperti halnya dalam penelitian ini.

Dimana dalam tahap observasi yang dilakukan, di temukan hal yang menjadi penyebab stres kerja mampu mempengaruhi kinerja sumberdaya. Salah satunya adalah stres kerja akan membuat seseorang menjadi lebih tau diri dan akan bertanggung jawab terhadap jabatannya. Secara teori, kinerja digunakan sebagai alat penilaian kesehatan suatu perusahaan atau organisasi yang perlu dievaluasi dan dapat dinyatakan dengan pengukuran kinerja. Pengukuran kinerja merupakan bagian dari sistem manajemen yang mencakup pengukuran untuk menentukan apa yang harus dilakukan dan mengevaluasi karyawan. Kinerja juga dapat dikatakan sebagai alat untuk mengukur seberapa jauh keberhasilan suatu perusahaan yang telah dicapai dan dapat pula digunakan sebagai alat untuk memprediksi keberhasilan perusahaan dimasa yang akan dating (Yuwono dkk., 2004).

Penelitian ini sejalan dengan penelitian yang dilakukan Fitrianingsih, (2016) dan Usman (2004) dimana stres kerja selalu mampu menjelaskan arah hubungannya dengan kinerja karyawan yang menunjukkan hubungan yang sedang atau selalu searah dan berhubungan secara negatif atau berlawanan. Hal ini berarti bahwa pada tingkat stres kerja terendah maka kinerja karyawan akan meningkat, tetapi peningkatan jumlah stres yang rendah dapat meningkatkan kinerja hanya sampai pada titik tertentu. Sedangkan pada tingkat stres kerja yang tinggi maka kinerja relatif akan menurun.

Implikasi dari penelitian ini adalah pemilihan stres kerja sebagai variabel yang mempengaruhi kinerja sumberdaya insani dalam sebuah bank sudah tepat. Sehingga stres kerja dapat dijadikan sebuah salah satu tolak ukur dalam menilai perkembangan sebuah perusahaan atau birokrasi. Khusus perusahaan di Makassar baik swasta ataupun milik pemerintah, sebaiknya proses peningkatan kinerja sumberdaya menggunakan stres kerja yaitu dengan cara penekanan terhadap aturan yang mampu meningkatkan keinginan karyawan dalam bekerja.

\section{Inovasi Produk terhadap Kinerja Sumberdaya Insani Perbankan Syariah di Kota Makassar}

Hasil yang ditemukan pada perhitungan statistik, diketahui bahwa inovasi produk tidak berpengaruh terhadap kinerja sumberdaya insani pada PT Bank BNI Syariah Cabang Makassar. Inovasi produk yang dikembangkan oleh kalangan manajemen perbankan sepertinya tidak membuat setiap karyawan mampu berprestasi sebagaimana yang diharapkan. Sebaliknya inovasi hanya sebagai pemicu atau penarik simpati bagi konsumen untuk menjadi pelanggan utama dalam melakukan transaksi dengan perbankan. Ketidakjelasan penciptaan inovasi sebagai salah satu langkah dalam menciptakan kinerja sumberdaya menuai per- 
masalahan yang diakibatkan tidak adanya keunggulan tersendiri dalam hal kinerja sumberdaya menjadi lebih baik.

Sebaliknya inovasi hanya di jadikan sebagai salah satu model modern yang tidak mampu bersaing dalam memperbaiki mutu sumberdaya manusia khususnya kinerja sumberdaya itu sendiri. Terobasan yang menuai banyak masalah di era modern sekarang ini sangat membuat simpati semua kalangan khususnya mengenai perbaikan kinerja sumberdaya. Walaupun dalam teori inovasi dijadikan sebagai salah satu bentuk yang diciptakan secara murni melalui alam fikiran manusia.

Sebagaimana teori yang sejalan dengan penelitian ini adalah teori Munandar (2008) bahwa salah satu aspek terpenting di dalam perusahaan adalah sumber daya manusia. Agar perusahaan terus berkembang dan terus memberikan nilai tambah diperlukan peningkatan kualitas sumber daya manusianya. Perusahaan dibentuk berdasarkan suatu visi dan misi, yang dalam pelaksanaan visi dan misi tersebut dikelola oleh manusia-manusia yang saling bekerja sama. Interaksi karyawan dengan pekerjaan dan lingkungan kerjanya menghasilkan pelayanan jasa. Berdasarkan unjuk kerja-nya, karyawan mendapatkan imbalan yang berdampak pada kinerja. Sebagai hasil atau akibat lain dari proses bekerja, karyawan dapat mengalami stress, yang dapat berkembang sebagai karyawan yang sakit, sehingga tidak dapat bekerja lagi secara maksimal.

Tekanan yang berkembang sedemikian rumit di kalangan perusahaan baik swasta ataupun milik pemerintah, menjadikan sumber daya manusianya menjadi tidak mampu bersaing bahkan terpinggirkan oleh sebuah perkembangan dunia. Sebagai salah satu dampaknya, inovasi produk hanya membuat kalangan sumberdaya menjadi tidak searah antara keinginan fikiran sendiri dalam berkreasi atau mengikuti arah keinginan produk yang diciptakan oleh manajemen perbankan.

Salah satu faktor penyebabnya adalah menjamurnya lembaga keuangan yang tidak kalah bagus apabila dibandingkan dengan produk yang ditawarkan oleh perbankan. Hal ini dapat dirasakan melalui tidak semua kalangan masyarakat menginginkan inovasi yang ditawarkan oleh bank yang beraktivitas dibawah basis syariah. Faktor yang lain adalah masyarakat menganggap bahwa inovasi yang ditawarkan oleh bank berbasis syariah tidak ada bedanya dengan inovasi yang ditawarkan oleh bank konvensional sebagaimana biasanya. Anggapan ini diyakini bahwa apa yang ditawarkan tidak selamanya sejalan dengan aplikasinya, sebagai bukti bahwa bank syariah menawarkan bagi hasil akan tetapi kenyataan sangat berbeda jauh karena tidak ada bedanya dengan tawaran bank konvensional dalam hal ini tingkat bunga.

Oleh karena itu, implikasi dari penelitian ini adalah bahwa pilihan inovasi produk sebagai variabel dalam penelitian ini dapat dianggap tepat untuk menilai kinerja sumber daya. Akan tetapi inovasi produk yang ditawarkan seharus-nya mampu menyeimbangkan antara kinerja sumberdaya dan target yang di inginkan oleh lembaga atau perusahaan itu sendiri. Akan tetapi, dalam kehidupan seharihari inovasi menjadikan karyawan lembaga menjadi tertekan bahkan barakibat pada stres yang berkepanjangan yang memunculkan berbagai interaksi yang sangat berlawanan dengan keinginan dunia kerja. 
Sebagai langkah awal, sebaiknya inovasi dijadikan sebagai pola konsumsi yang tidak wajib untuk dikembangkan atau dijalankan oleh orang perseorangan karyawan perusahaan. Sebab hal ini dapat berujung pada tidak terkonsentrasinya fikiran karyawan akibat adanya tekanan yang terlalu berlebihan sehingga akan berdampak pada keluhan bahkan penolakan yang sewaktu-waktu dapat terjadi yang dilakukan oleh karyawan perusahaan itu sendiri.

\section{KESIMPULAN}

Berdasarkan uraian hasil penelitian dan pembahasan terkait pengaruh perubahan organisasi, stress kerja dan inovasi produk terhadap kinerja sumber daya insani pada PT. Bank BNI Syariah cabang Makasar, maka dapat disimpulkan bahwa perubahan organisasi tidak berpengaruh terhadap kinerja sumberdaya insani pada PT Bank BNI Syariah Cabang Makassar. Hal ini berbanding terbalik dengan stress kerja. Stres kerja berpengaruh terhadap kinerja sumberdaya insani Bank BNI Syariah di Kota Makassar. Proses ini menjadi lebih jelas dimana stres kerja merupakan sebuah variabel yang mampu menjelaskan naik turunnya sebuah kinerja seseorang sehingga mampu memberikan sebuah perubahan pada perusahaan. Inovasi produk tidak berpengaruh terhadap kinerja sumberdaya insani pada PT Bank BNI Syariah Cabang Makassar. Inovasi produk yang dikembangkan oleh kalangan manajemen perbankan tidak membuat setiap karyawan mampu berprestasi sebagaimana yang diharapkan. Sebaliknya inovasi hanya sebagai pemicu atau penarik simpati bagi konsumen untuk menjadi pelanggan utama dalam melakukan transaksi dengan perbankan.

\section{REFERENCES}

Al Hasan, F. A., \& Maulana, M. I. (2016). Meningkatkan Kualitas Sumber Daya Insani Di Lembaga Kuangan Syariah Dalam Menghadapi Persaingan Global. Sosio Didaktika: Social Science Education Journal, 3(1), 27-36.

Alamsyah, H. (2012). Perkembangan dan Prospek Perbankan Syariah Indonesia: Tantangan dalam Menyongsong MEA 2015. Makalah Disampaikan Pada Ceramah Ilmiah Ikatan Ahli Ekonomi Islam (IAEI), Milad Ke-18 IAEI,(13 April 2012).

Awwalin, D. . (2014). Peluang, Tantangan, Dan Prospek Perbankan Syariah Indonesia Dalam Menghadapi Persaingan Masyarakat Ekonomi ASEAN (MEA) 2015. Jurnal Mahasiswa Universitas Surabaya, 3(21), 274-282.

Barling, J., Kelloway, E. K., \& Iverson, R. D. (2003). High-quality work, job satisfaction, and occupational injuries. Journal of Applied Psychology, 88(2), 276-283. https://doi.org/10.1037/0021-9010.88.2.276

Desky, H. (2014). Pengaruh Etos Kerja Islami dan Gaya Kepemimpinan Terhadap Kinerja Karyawan Rumah Makan Ayam Lepaas Lhokseumawe. INFERENSI: Jurnal Penelitian Sosial Keagamaan, 8(2), 459-478.

Fitrianingsih, A. (2016). Hubungan Antara Stress Kerja Dengan Kinerja Karyawan Pada Agen Ajb Bumiputera 1912 Kantor Cabang Pancoran Mas Depok. In Ilmu Sosial \& Ilmu Politik. 
Kunuz: Journal of Islamic Banking and Finance Vol. 1, No.2 (2021):95-106

Website: http://ejournal.iain-manado.ac.id/index.php/kunuz

ISSN 2807-615X (online) ISSN 2807-680X (print)

Gunawan, C. I., Mukoffi, A., \& Handayanto, A. J. (2017). Strategi Perbankan Syariah (Issue 1).

Hardana, A. (2015). Manajemen Sumber Daya Insani. Al-Masharif: Jurnal Ilmu Ekonomi Dan Keislaman, 3(1), 115-126.

Haryanto, R. (2017). Urgensi Sumber Daya Insani dalam Membentuk Budaya Kerja Islami. Islamuna: Jurnal Studi Islam, 4(1), 176-207.

Jawas, S. M. . (2011). Pengaruh Sikap Perubahan Organisasi Terhadap Kinerja Pegawai UIN Syarif Hidayatullah Jakarta. UIN Syarif Hidayatullah Jakarta.

Laihad, R. A., Lengkong, V. P., \& Saerang, R. T. (2019). Analisis Faktor-Faktor Yang Mnyebabkan Resistensi Dalam Proses Perubahan Organisasi Di Otoritas Jasa Keuangan Sulawesi Utara, Gorontalo Dan Maluku Utara Di Manado Analysis of Factors That Cause Resistance in the Process of Organizational Change in the Fin. Jurnal EMBA: Jurnal Riset Ekonomi, Manajemen, Bisinis Dan Akuntansi, 7(1), 531-540.

Mas'ud. (2002). Mitos Manajemen Sumberdaya Manusia. Badan Penerbit Universitas Diponegoro.

Munandar. (2008). Psikologi Industri dan Organisasi. Universitas Indonesia (UIPress).

Ningsih, E. R. (2015). Analisis Potensi Penerimaan Kualitas Alumni Program Studi Ekonomi Syari ah Stain Kudus Ditinjau Dari Perspektif Stakeholder. Jurnal Penelitian, 9(1).

Rademakers, M. (2005). Corporate universities: driving force of knowledge innovation. Journal of Workplace Learning, 3(2).

Robbins. (2003). Teori Organisasi Struktur, Desain \& Aplikasi Edisi 3. Penerbit Arcan.

Usman, N. (2004). Konteks Implementasi Berbasis Kurikulum. PT. Raja Grafindo Persada.

Yuwono, S., Sukarno, E., \& Ichsan, M. (2004). Petunjuk Praktis Penyusunan Balanced Scorecard: Menuju Organisasi Yang berfokus Pada Strategi. PT Gramedia Pustaka Utama.

Zulkarnain, Z., \& Hadiyani, S. (2014). Peranan Komitmen Organisasi dan Employe Engagement Terhadap Kesiapan Karyawan untuk Berubah. Jurnal Psikologi, 41(1), 17-33. 